\title{
PKM KELOMPOK KESEHATAN REPRODUKSI DI SMPN 226 PONDOK LABU JAKARTA SELATAN
}

\author{
Mila Citrawati $^{1}$, Yanti Harjono², Citra Ayu Aprilia ${ }^{3}$ \\ ${ }^{1}$ Departemen Ilmu Faal Fakultas Kedokteran Universitas Pembangunan Nasional Veteran Jakarta \\ Email : milacitra@gmail.com \\ ${ }^{2}$ Departemen Ilmu Kesehatan Masyarakat Fakultas Kedokteran Universitas Pembangunan Nasional Veteran Jakarta \\ Email : yantiharjono@gmail.com \\ ${ }^{3}$ Departemen Farmakologi Fakultas Kedokteran Universitas Pembangunan Nasional Veteran Jakarta \\ Email : citra.ayuaprilia@gmail.com
}

\begin{abstract}
ABSTRAK
Pubertas merupakan suatu tahap penting dalam proses tumbuh kembang anak. Perubahan fisik yang mencolok terjadi selama proses ini, kemudian diikuti oleh perkembangan ciri-ciri seksual sekunder, perubahan komposisi tubuh. Pada fase masa remaja tidak hanya terjadi perubahan fisik saja namun juga terjadi perubahan hormonal, psikologis dan sosial. Masa pubertas pada perempuan dimulai saat usia antara 8-13 tahun, sedangkan pada laki-laki usia antara 10-15 tahun. Maturasi seksual akan melibatkan organ reproduksi baik pada remaja laki-laki maupun perempuan. Pengetahuan tentang kesehatan reproduksi pada remaja dapat mengukur tingkat pengetahuan remaja mengenai isu kesehatan reproduksi. Siswa SMPN 226 Pondok Labu, Jakarta Selatan, berasal dari berbagai wilayah tidak hanya dari daerah sekitar Pondok Labu Jakarta Selatan. Sehingga latar belakang keluarga siswa sangat bervariasi dari segi pendidikan, status ekonomi dan sosial, serta kultur. Hal ini memungkinkan pemahaman tentang kesehatan reproduksi pada remaja sangat bervariasi di sekolah ini. Pengabdian kepada masyarakat tentang pengetahuan reproduksi pada 288 siswa SMPN 226 Pondok Labu Jakarta Selatan ini bertujuan meningkatkan pengetahuan kesehatan reproduksi pada siswa yang dalam fase usia pubertas. Penyuluhan tentang kesehatan reproduksi meliputi pubertas dan semua hal berkaitan dengan proses pubertas dilakukan dengan media audio dan visual dengan memanfaatkan ruang kelas. Untuk mengetahui tingkat pemahaman siswa dilakukan pengisian kuesioner sebelum dan sesudah penyuluhan. Hasil yang dicapai dari kegiatan ini adalah peningkatan pengetahuan peserta tentang pubertas dan kesehatan reproduksi.
\end{abstract}

Kata kunci: kesehatan reproduksi, pubertas, pengetahuan

\section{PENDAHULUAN}

Berdasarkan Sensus Penduduk 2010, ada 40,4 juta penduduk berumur 15-24 tahun yang terdiri dari 16,6 juta pria dan 12,8 juta wanita dengan status belum kawin (BPS, 2010). Jumlah usia muda 15-24 tahun diperkirakan sekitar 17 persen dari total penduduk Indonesia.(SDKI 2012)

Menurut SDKI 2012 ada tujuh lembaga pemerintahan di Indonesia bertugas memetakan kebutuhan remaja. Tujuh lembaga tersebut adalah Kementerian Pendidikan dan Kebudayaan (Kemendikbud), Kementerian Kesehatan (Kemenkes), Kementerian Sosial (Kemensos), Kementerian Agama (Kemenag),Kementerian Pemberdayaan Wanita dan Perlindungan Anak (KPP dan PA), Kementerian Pemuda dan Olahraga (Kemenpora), dan Badan Kependudukan dan Keluarga Berencana Nasional (BKKBN). Berbagai Lembaga Swadaya Masyarakat (LSM) juga telah membantu secara aktif dalam penyediaan informasi, edukasi, dan pembinaan terhadap remaja di Indonesia sejak tahun 1986.

Kementrian Kesehatan bersama kementrian lainnya menyusun Strategi dan Kebijakan Kesehatan Reproduksi tahun 2005-2010. Pemerintah Indonesia harus menempatkan kesehatan reproduksi sebagai salah satu prioritas dalam pembangunan nasional, demi peningkatan status dan derajat kesehatan sekaligus pembangunan sumber daya manusia di Indonesia. Kebijakan ini juga menjadi dasar dan arah bagi berbagai sektor, pemerintah daerah, LSM, profesional, swasta, dan khalayak bisnis demi menyukseskan program kesehatan reproduksi di Indonesia (SDKI 2012).

Usia remaja (laki-laki dan perempuan 10 - 14 tahun) ditandai dengan perubahan biologis, kognitif, emosi dan sosial, seiring terjadinya pubertas (WHO, 2011). Pubertas merupakan suatu tahap penting 
dalam proses tumbuh kembang anak. Pubertas adalah penanda mulainya pertumbuhan dan perkembangan biologis menjelang remaja. Masa pubertas pada perempuan dimulai saat usia antara 8-13 tahun, sedangkan pada laki-laki usia antara 10-15 tahun (Batubara JR. 2010). Perubahan fisik yang mencolok terjadi selama proses ini, diikuti oleh perkembangan ciri-ciri seksual sekunder (maturasi seksual), perubahan komposisi tubuh serta perubahan maturasi tulang yang cepat (peningkatan tinggi badan), diakhiri dengan epifisis yang tertutup. Terjadi juga peningkatan massa tulang dan perubahan komposisi tubuh serta terbentuk perawakan akhir dewasa. Namun demikian pada penelitian Handayani 2017 tinggi badan tidak dipengaruhi oleh usia menarche dan pubertas.

Terdapat variasi onset, durasi dan kecepatan proses ini, sehingga penampilan fisik dapat sangat bervariasi (Stang J, 2005). Awitan pubertas dipengaruhi oleh beberapa sinyal termasuk neurotransmiter dan neuropeptida yang berasal dari hipotalamus yang diteruskan ke perifer dan gonad. Variasi usia pubertas melibatkan $74 \%$ faktor genetik dan $26 \%$ faktor lingkungan. Faktor lingkungan meliputi letak geografis, status sosial ekonomi, infeksi, iklim, stresor, dan gangguan pada sistem endokrin yang mempengaruhi jaringan sinyal hipotalamus.

Tanda awal perkembangan pubertas pada anak lelaki adalah pembesaran ukuran testis dan penipisan kulit skrotum, kemudian diikuti oleh pigmentasi skrotum, pembesaran penis dan kemudian terlihat pertumbuhan rambut pubis. Dengan demikian, ukuran volume testis dapat juga digunakan untuk menentukan usia awitan pubertas. Pertumbuhan ini terjadi akibat perkembangan tubulus seminiferus di bawah pengaruh stimulasi FSH (Sherwood 2016). Rambut ketiak tumbuh menyertai rambut pubis, sedangkan kumis dan janggut baru tumbuh kemudian. Pada anak lelaki terjadi perubahan suara mengikuti pacu tumbuh laring. Hal ini terjadi bila proses pubertas sudah berlangsung beberapa waktu. Rata-rata genitalia mencapai tahap dewasa selama 3 tahun setelah mulai berkembang, tapi beberapa anak lelaki dapat menyelesaikan tahapan ini dalam waktu 1.8 tahun, sementara anak lainnya memerlukan waktu sampai 4.7 tahun. (Sherwood, 2016)

Perkembangan pubertas anak perempuan biasanya dimulai dengan budding (tumbuhnya payudara), namun sekitar $15 \%$ dari perempuan normal mengalami perkembangan rambut pubis yang mendahului perkembangan payudara. Rambut pubis mulai tumbuh sekitar usia 11 tahun. Bersamaan dengan tumbuhnya rambut pubis, tumbuh pula rambut ketiak. Jika terdapat ketidaksesuaian antara tahap perkembangan payudara dan rambut pubis maka sangatlah penting untuk mengklasifikasikan kedua tahap perkembangan tersebut secara terpisah. Perkembangan payudara terutama dikendalikan oleh sekresi estrogen dari ovarium sedangkan perkembangan rambut pubis dipengaruhi oleh sekresi androgen dari adrenal. Tahap perkembangan payudara perempuan tidak bersifat absolut. Beberapa perempuan dewasa tidak pernah mencapai tahap 4 dan beberapa perempuan mengalami perkembangan langsung dari tahap 3 ke 5. Perkembangan payudara unilateral masih normal pada awal pubertas dan mungkin menetap selama 6 bulan sebelum timbulnya tunas payudara yang lain. Haid merupakan tahap akhir pubertas pada perempuan dengan terjadinya haid secara periodik, maka akan berakhir pertumbuhan fisik pada perempuan. Mempersiapkan psikologi remaja sejak awal sangat penting agar muncul respon positif menghadapi menarche sehingga proses tersebut dapat dihadapi dengan tenang. (Yusuf Y, 2014). Kemajuan kondisi sosioekonomi di abad ini berdampak pada onset menarche yang lebih cepat. (Karapanou O, Papadimitriou A, 2010).

Pada perempuan pubertas ditandai adanya menarch. Usia menarch antara lain dipengaruhi status gizi dan ekonomi, Pada penelitian Amaliah 2012, didapatkan hasil usia menarch pada anak dengan stunting terjadi lebih lambat dibanding dengan anak dengan status gizi normal (Amaliah N,2012). Terjadinya tanda-tanda pubertas dipengaruhi banyak faktor antara lain adalah indeks massa tubuh (IMT). Pada penelitian Rosenfield RL (2009) pubertas mulai lebih awal pada anak perempuan Amerika-Meksiko dan kulit hitam non Hispanik dengan IMT normal. (Rosenfield RL, 2009). 
Pada fase masa remaja tidak hanya terjadi perubahan fisik saja namun juga terjadi perubahan hormonal, psikologis dan sosial. Perubahan psikososial pada remaja dapat mengakibatkan masalah hubungan orang tua dan anak (Batubara JR. 2010). Siswa SMPN 226 Pondok Labu Jakarta Selatan berasal dari berbagai wilayah tidak hanya dari daerah sekitar Pondok Labu Jakarta Selatan. Hal ini disebabkan sistem penerimaan siswa melalui jalur khusus dan jalur umum. Sehingga latar belakang keluarga siswa sangat bervariasi dari segi pendidikan, status ekonomi dan sosial, serta kultur. Hal ini memungkinkan pemahaman tentang kesehatan reproduksi pada remaja sangat bervariasi di sekolah ini.

Pengetahuan tentang kesehatan reproduksi pada remaja dapat mengukur tingkat pengetahuan remaja mengenai isu kesehatan reproduksi. Penyuluhan tentang kesehatan reproduksi meliputi pubertas dan semua hal berkaitan dengan proses pubertas dilakukan dengan media audio dan visual dengan memanfaatkan ruang kelas siswa SMPN 226 Pondok Labu Jakarta Selatan

\section{METODE PELAKSANAAN PKM}

Langkah mengatasi permasalahan mitra terdiri dari observasi ke SMPN 226 Pondok Labu, Jakarta Selatan, identifikasi permasalahan mitra, penentuan solusi, koordinasi dengan kepala sekolah, pelaksanaan kegiatan penyuluhan kesehatan reproduksi tentang pubertas, dan evaluasi program. Pelaksanaan kegiatan penyuluhan kesehatan reproduksi pada siswa SMPN 226 Pondok Labu, Jakarta Selatan menghadapi pubertas terdiri dari penyuluhan dengan metode ceramah dan pemutaran video, serta pembagian leaflet pubertas baik kepada siswa maupun kepada guru wali kelas.

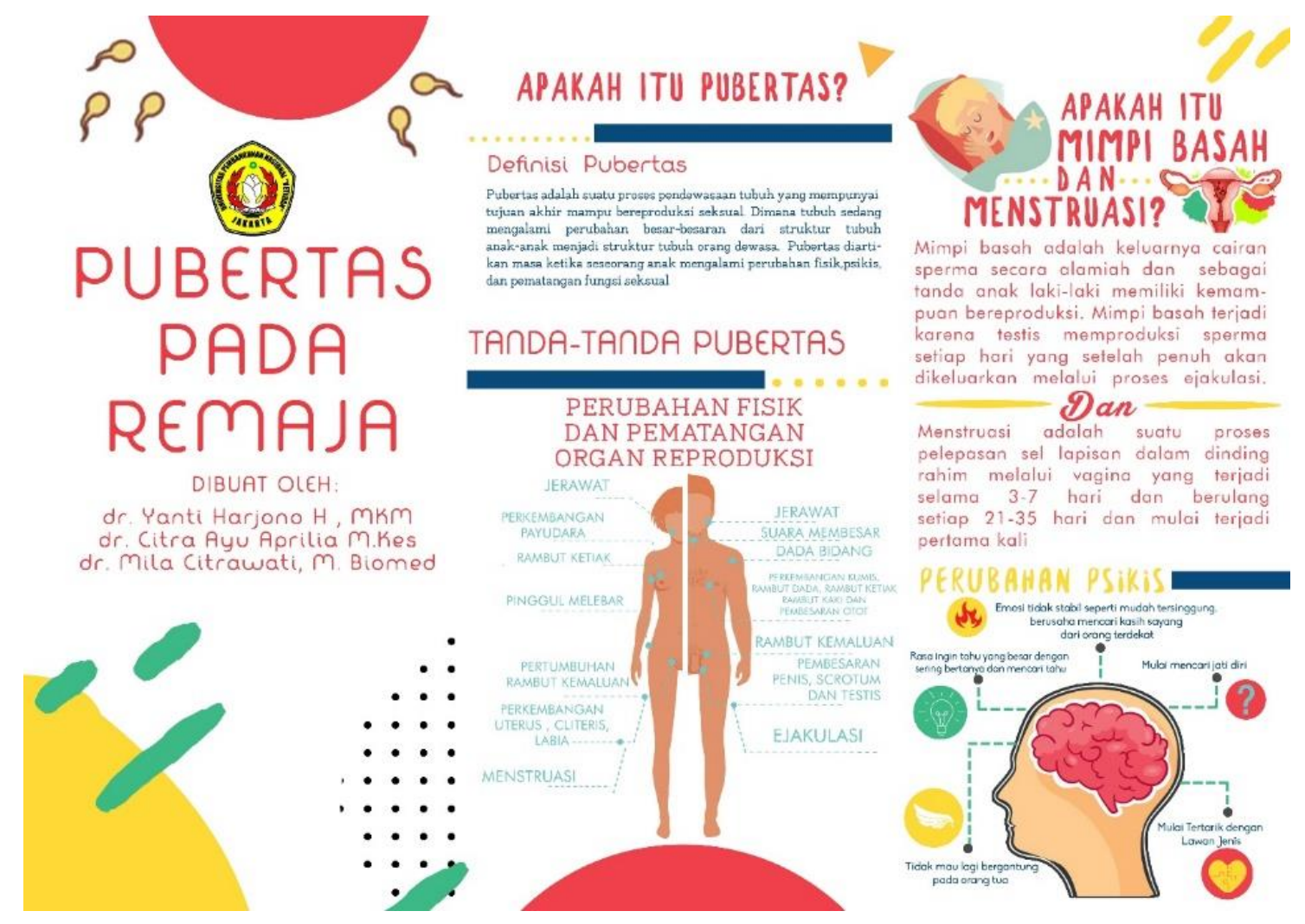

Gambar 1. Leaflet Halaman Muka 

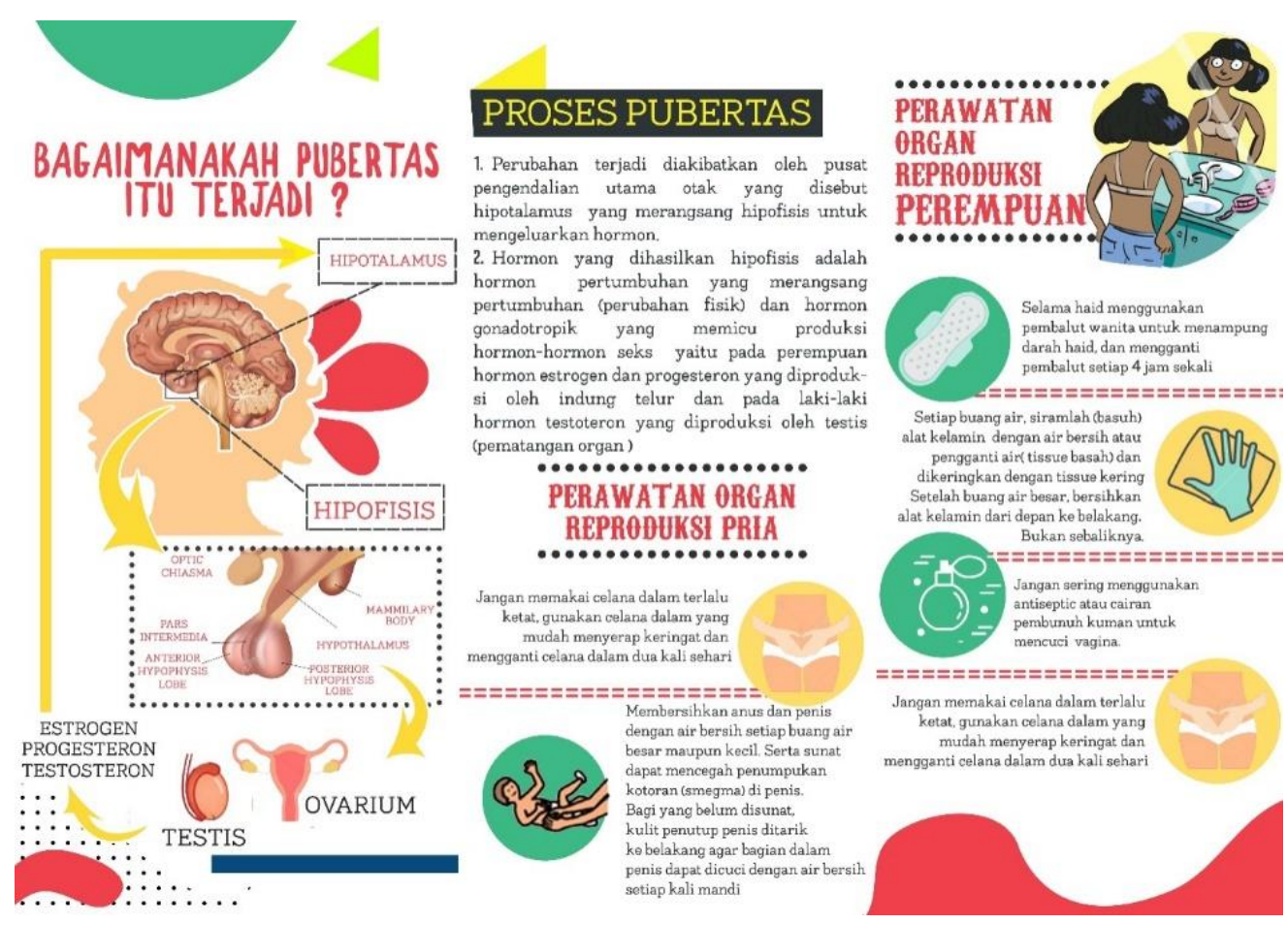

Gambar 2. Leaflet Halaman Belakang

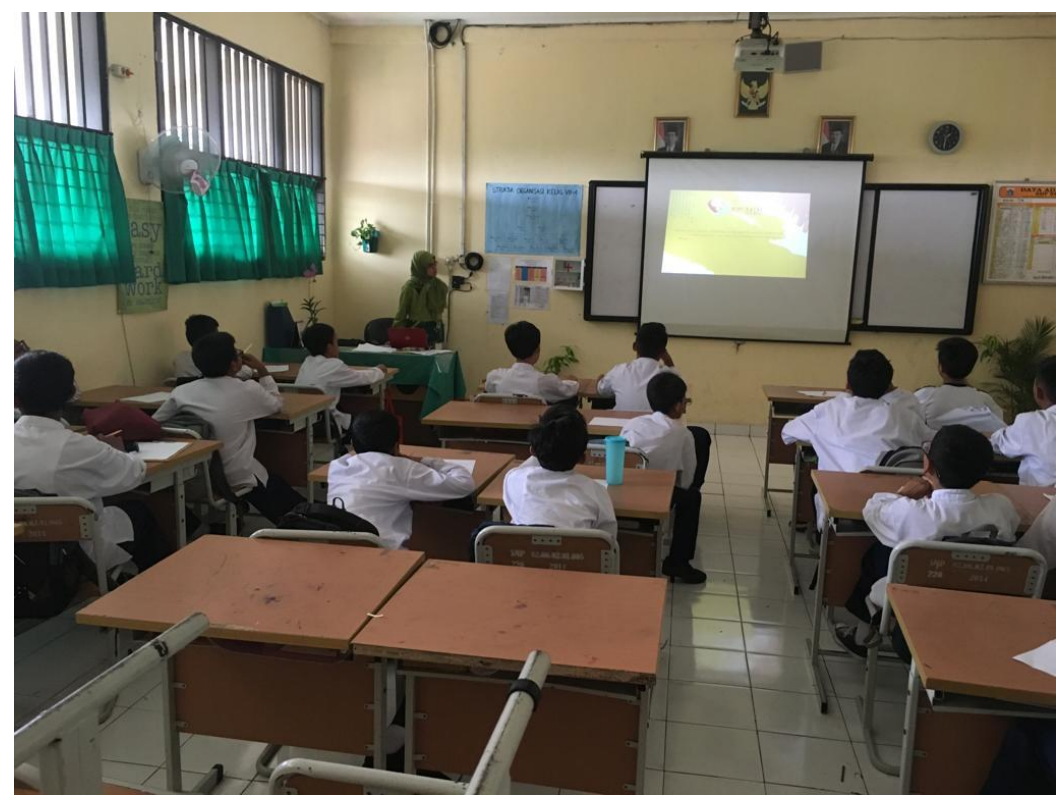

Gambar 3. Bersama-sama Melihat Film Animasi Edukasi Pubertas

Evaluasi kegiatan bertujuan untuk mengetahui pemahaman siswa terhadap materi penyuluhan kesehatan reproduksi. Evaluasi dilakukan dengan memberikan post-test tentang materi penyuluhan. Pada akhir kegiatan penyuluhan kesehatan reproduksi dilakukan pembagian leaflet. Leaflet diberikan kepada pihak sekolah sebagai koleksi bahan bacaan di perpustakaan dan referensi guru menghadapi pertanyaan siswa seputar pubertas. Leaflet berisi materi tentang kesehatan reproduksi secara singkat. 


\section{HASIL DAN PEMBAHASAN}

Penyuluhan kesehatan reproduksi bertujuan memberikan informasi tentang kesehatan reproduksi remaja melalui metode audio maupun visual. Penggunaan media audio dan visual dalam penyuluhan kesehatan reproduksi di SMPN 226 Pondok Labu, Jakarta Selatan ini bertujuan materi kesehatan reproduksi dapat dengan mudah dimengerti oleh siswa. Kedua media yang digunakan dalam kegiatan penyuluhan saling mendukung penyampaian materi penyuluhan. Penyuluhan melalui media audio (ceramah) diperkuat dengan media visual (leaflet dan video animasi) sehingga seluruh informasi dapat dipahami dengan mudah oleh siswa. Materi penyuluhan meliputi kesehatan reproduksi khususnya tentang pubertas, organ reproduksi, menstruasi, mimpi basah, dan perawatan organ reproduksi.

Hasil evaluasi, secara keseluruhan siswa memahami materi penyuluhan. Selain post test, siswa diberi kesempatan bertanya tentang materi penyuluhan. Cukup banyak pertanyaan yang diajukan siswa tentang materi penyuluhan. Target jumlah peserta terpenuhi $90 \%$ siswa dilakukan penyuluhan dan menerima materi yang dilakukan oleh tim pengabdian kepada masyarakat. Setelah dilakukan tanya jawab dapat dilihat bahwa ada peningkatan pengetahuan dari siswa mengenai pubertas dan kesehatan reproduksi. Semua materi penyuluhan dapat disampaikan oleh tim pengabdian kepada masyarakat dengan waktu yang terbatas.

\section{KESIMPULAN DAN SARAN}

Kegiatan penyuluhan kesehatan reproduksi di SMPN 226 Pondok Labu, Jakarta Selatan menambah pengetahuan siswa tentang pubertas dan merawat organ reproduksi. Guru membutuhkan modul tentang kesehatan reproduksi yang lebih lengkap untuk menghadapi siswa di usia puber dan melakukan penyuluhan mandiri.

\section{UCAPAN TERIMAKASIH}

Tim pengabdian kepada masyarakat mengucapkan terimakasih kepada Universitas Pembangunan Nasional "Veteran" Jakarta atas dukungan dana yang diberikan sehingga kegiatan pengabdian kepada masyarakat terhadap kelompok kesehatan reproduksi di SMPN 226 Pondok Labu, Jakarta Selatan dapat terlaksana dengan baik. Terimakasih juga ditujukan kepada Kepala Sekolah dan Wali Kelas serta seluruh siswa kelas 7 SMPN 226 Pondok Labu, Jakarta Selatan atas kerjasamanya selama kegiatan pengabdian kepada masyarakat berlangsung.

\section{REFERENSI}

Amaliah N, Sari K, Rosha BC. (2012). Status Tinggi Badan Pendek Berisiko Terhadap Keterlambatan Usia Menarche Pada Perempuan Remaja Usia 10-15 Tahun. Penel Gizi Makan, 35(2): 150-158

Badan Pusat Statistik. (2010)

Batubara JR. (2010). Perkembangan Remaja. Sari Pediatr, Vol. 12. 1: 21

Handayani R, et al. (2017). Usia Pubertas dan Menarche Terhadap Tinggi Badan Mahasiswa Kebidanan, Jurnal MKMI, halaman 23

Karapanou O, Papadimitiou A. (2010), Determinants of Menarche. Reproductive Biology and Endocrinology, page 6 
Riskesdas. (2013).

Rosenfield RL, Lipton RB, Drum ML. (2009). Thelarche, Pubarche, And Menarche Attainment In Children With Normal And Elevated Body Mass Index. Pediatrics, 123(1):84-8.

Sherwood, L. (2016) Human Physiology: From Cells too System $9^{\text {th }}$ Edition, Belmont: Brook/Cole

Stang J, Story M (eds) (2005). Guidelines for Adolescent Nutrition Services, page 1

Survei Demografi dan Kesehatan Indonesia, Kesehatan Reproduksi Remaja. (2012)

WHO. (2011). The Sexual And Reproductive Health Of Younger Adolaescents, Research Issues In Developing Countries.

Yusuf Y, Kundre R, Rompas S. (2014). Hubungan Pengetahuan Menarche Dengan Kesiapan Remaja Putri Menghadapi Menarche di SMP Negri 3 Tidore Kepulauan. Manado: Universitas Sam Ratulangi 